\title{
Biofuels and Sustainable Economy
}

\author{
Andrzej L Wasiak* \\ Department of Production Management, Bialystok University of Technology, Poland
}

Submission: March 14, 2017; Published: March 30, 2017

"Corresponding author: Andrzej L Wasiak, Department of Production Management, Bialystok University of Technology, Wiejskastr, 45A, 15-351 Bialystok, Poland, Tel: +48-85-746-98-47; Email: awasiak@pb.edu.pl

\section{Mini Review}

Shortage of fossil energetic resources, parallel to harmful effects to natural environment became a challenge to contemporary economies. Both factors mentioned constitute the real problems especially that they cause contradicting results. Expected shortages of fossil fuels may lead to energy crisis, while further use of those fuels leads to almost catastrophic environmental problems.

In this situation bio fuels are frequently recommended [14], and considered as the replacement for fossil ones. It is bellied that use of bio fuels may contribute to mitigation of the danger of energy crisis, as well as of those fuels to reduce environmental threats. Implementation of bio fuels is also considered as important contribution towards achieving sustainability of agriculture [5-7].

Recent publications by Wasiak \& Orynycz [8-10] present analysis of energy efficiency of biofuel production systems, as well as offer an attempt to redefine energetic aspects of sustainability Wasiak [11]. It was shown that (EROEI type) indicator of energetic efficiency, $\varepsilon$, of the energy production system built of, $i$, subsystems can be expressed by the law of additivity of reciprocals of partial efficiencies, $\varepsilon_{i^{\prime}}$ describing each of subsystems:

$$
1 / \varepsilon=\sum_{-} \mathrm{i} 1 / \varepsilon_{-} \mathrm{i}
$$

The partial efficiency of a subsystem, in turn, is defined as the ratio of the energy, $E_{t o t}$ obtained (during a chosen period of time) from the whole system to the sum of the energy inputs, $E_{k^{\prime}}$ needed to maintain functioning of that subsystem, i.e.:

$$
\varepsilon_{-} \mathrm{i}=\mathrm{E}_{-} \mathrm{tot} /\left(\sum_{-} \mathrm{kE} \_\mathrm{k}\right) \mathrm{i}
$$

Application of the above approach to the analysis of agricultural part of bio fuel production systems [...] have shown that energetic efficiency of s.c. "energetic" plantation varies from about 10 to about 200 depending upon the choices of plant species being cultivated, production technology, productiveness of machinery used, as well as some aspects of production organization. On the other hand, Transportation of goods between fields, and transportation of crops from plantation to the factory converting biomass into bio fuel require additional inputs of energy. For the case of rapeseed grain transportation on the distance of $100 \mathrm{~km}$, it was estimated, that energetic efficiency of this part of production system varies between 100 and 150 depending on the type of transportation means used.

Results of various combinations of the values above mentioned are given in Table 1. It is seen, that in some combinations the effects are quite substantial. The effects are mostly pronounced when both values of effectiveness, being combined, are large. In these cases the aggregate value is reduced to almost half of each contributing ones.

It has to be mentioned, that further decrease of energetic effectiveness should be expected due to energy inputs necessary to achieve conversion of biomass into bio fuel in the industrial part of the production system. Conclusion, that can be drawn from those computations, shows that in order to achieve maximum efficiency, production system dedicated to bio fuels production, should contain as small as possible number of energy consuming processes, and should be built basing on high yield plants, and highest energy content crops.

Further question is how the energy efficiency of bio fuel production system corresponds to sustainability of agriculture, as well as in wider sense sustainability of the whole economy, at least on the level of particular Country. It has to be pointed out that agriculture is not only one resource providing biomass for mankind. Biomass is being harvested also from other sources like forestry, fisheries, etc. Some of those resources are cultivated, some still belong to wild nature.. Any of those resources, however, require inputs of energy in order to obtain some amount of useful biomass. Consequently, the considerations given above are applicable to all of the resources. Considering biomass as replacement of fossil fuels one has to keep in mind that such use competes with other applications like food production or construction materials. Evidently, although with slightly different results, one may assume that a unit of land cultivated for energetic purposes may cover energy needs of other, 
i.e. "non-energetic" plantations at the proportion given by numbers taken from Table 1, depending upon technological and agricultural factors corresponding to particular case. Consequently, these numbers give the idea of necessary reduction of other crops in favor of "energetic" ones to achieve sustainability or at least selfsufficiency of agriculture itself. This consideration does not consider energy needed to supply agriculture with industrial products, like machinery, fertilizers, etc. The development of technology, and biotechnology may improve the situation to some extent through developing more efficient tools and conversion methods, as well as an increase of productivity of biomass (e.g. through genetic modification of organisms). Also, in order to reduce the danger caused by competitive use of bio-resources, it seems advisable to develop technologies of energy production from wastes of biomass occurring in e.g. food production, so that edible parts of biomass would not undergo conversion to energy.

Table 1: Effect of energetic efficiency of transport on the energetic efficiency on aggregate efficiency of two sub systems.

\begin{tabular}{|c|c|c|c|c|}
\hline \multirow{2}{*}{ etr } & \multicolumn{4}{|c|}{ عagr } \\
\hline & 10 & 50 & 100 & 200 \\
\hline 245 & 9.7 & 41.6 & 71.1 & 110.2 \\
\hline 197 & 9.6 & 39.9 & 66.4 & 99.3 \\
\hline 116 & 9.3 & 35 & 53.8 & 73.5 \\
\hline
\end{tabular}

The above consideration could also be applied to discuss what part of land, should be converted to energetic production to replace fossil fuels in a degree covering whole needs of economy. This task extends the range of this paper. It seems, however, that assumption of such possibility is rather unrealistic.

\section{References}

1. Nigam S, Singh A (2011) Production of liquid bio fuels from renewable resources. Progress in Energy and Combustion Science 37: 52-68.

2. Manuel P (2017) Bioenergy -a Sustainable and Reliable Energy Source. Agri Res \& Tech: Open Access J 4(4): 555642.

3. Bharathiraja B, Chakravarthy M, Kumar R, Yuvaraj D, Jayamuthunagai J, et al. (2014) Biodiesel production using chemical and biological methods- A review of process, catalyst, acylacceptor, source and process variables. Renewable and Sustainable Energy Reviews 38(C): 368-382.

4. Abnisa F, Daud WMA, Husin WNW, Sahu JN (2011) Utilization possibilities of palm shell as a source of biomass energy in Malaysia by producing bio-oil in pyrolysis process. Biomass and Bio energy 35: 1863-1872.

5. Russo D, Dassisti M, Lawlorb V, Olabib AG (2012) State of the art of biofuels from pure plant oil. Renewable and Sustainable Energy Reviews 16(6): 4056-4070.

6. Alluvione F, Moretti B, Sacco D, Grignani C (2011) EUE (energy use efficiency) of cropping systems for a sustainable agriculture. Energy 36(7): 4468-4481.

7. Muller A (2009) Sustainable agriculture and the production of biomass for energy use. Climatic Change 94(3): 319-331.

8. Wasiak A, Orynycz O (2014) Formulation of a model for energetic efficiency of agricultural subsystem of biofuel production. IEEE International Energy Conference: ENERGYCON'2014 Croatia, pp. 13331337.

9. Wasiak A, Orynycz O (2015) The Effects of Energy Contributions into Subsidiary Processes on Energetic Efficiency of Biomass Plantation Supplying Biofuel Production System. Agriculture and Agricultural Science Procedia 7: 292-300.

10. Wasiak A, Orynycz O (2015) Modelling of the dependence of energetic efficiency of biomass plantations upon energy fluxes going into subsidiary processes accompanying biomass production", EUBCE, $23^{\text {rd }}$ European Biomass Conference and Exhibition, pp. 289-293.

11. Wasiak A (2016) The effect of biofuel production on sustainability of agriculture. Biol Syst Open Access 5: 171.

\section{Your next submission with Juniper Publishers will reach you the below assets}

- Quality Editorial service

- Swift Peer Review

- Reprints availability

- E-prints Service

- Manuscript Podcast for convenient understanding

- Global attainment for your research

- Manuscript accessibility in different formats

( Pdf, E-pub, Full Text, Audio)

- Unceasing customer service

Track the below URL for one-step submission https://juniperpublishers.com/online-submission.php 